\section{Birlesik Dünya Arastırma New Trends and Issues BD-CENTER Proceedings on Humanities and Innovasyon ve Yayıneılık Merkezi \\ Social Sciences}

Volume 8, Issue 2, (2021) 37-48 www.prosoc.eu

Selected paper of Selected papers of 11th World Conference on Educational Technology Researches (WCETR-2021) 02-03 June 2021

University of Kyrenia, Kyrenia, Cyprus

(ONLINE VIRTUAL CONFERENCE)

\title{
Analysis of academic studies on mobile technologies in the field of music education in Turkey
}

Kutbettin Kuyumcu*, Research Assistant, Department of Fine Art Education, Music Education, Ataturk Education Faculty, Hakkari University, Hakkari, Turkey

Ajda Aylin Can, Associate Professor, Department of Fine Art Education, Music Education, Ataturk Education Faculty, Marmara University, Istanbul, Turkey

Umit Kubilay Can, Associate Professor, Performance Arts Department, The Faculty of Fine Arts, Kocaeli University, Izmit, Turkey

\section{Suggested Citation:}

Kuyumcu, K., Can, A. A. \& Can, U. K. (2021). Analysis of academic studies on mobile technologies in the field of music education in Turkey. New Trends and Issues Proceedings on Humanities and Social Sciences. 8(2), 37-48. Available from: www.prosoc.eu

Received from June 21, 2021; revised from July 22, 2021; accepted from September 13, 2021.

Selection and peer review under responsibility of Prof. Dr. Huseyin Uzunboylu, Higher Education Planning, Supervision, Accreditation and Coordination Board, Cyprus.

${ }^{\circ} 2021$ Birlesik Dunya Yenilik Arastirma ve Yayincilik Merkezi. All rights reserved.

\begin{abstract}
The problem of this study is determining what types of studies involving mobile technology in the field of music education are carried out in Turkey and the analysis of these studies. The main objective of the study is to evaluate the mobile technology studies conducted in the field of music education in Turkey. The data obtained in the study were visualised using tables and the answers to the research questions were sought. From the data obtained in the study, it was observed that there were no scientific publications about mobile technologies in the music field before 2004. In line with these findings, it can be said that the number of academic studies on mobile technologies in music education has increased gradually in recent years. It has been suggested to increase the number of these studies and to implement music education programmes where music education processes are carried out with modern learning models.
\end{abstract}

Keywords: Mobile learning, mobile technologies, music education, academic studies, Turkey.

\footnotetext{
* ADDRESS FOR CORRESPONDENCE: Kutbettin Kuyumcu, Research Assistant, Department of Fine Art Education, Music Education, Ataturk Education Faculty, Hakkari University, Hakkari, Turkey.

E-mail address: kutbettinkuyumcu@hakkari.edu.tr
} 


\section{Introduction}

Education is considered as one of the most effective processes for the development of civilisations that enable to train and improve individuals in the society in line with the determined target behaviours. Ucan (1997) defines education as the process of creating desired changes in people's behaviours or giving them new desired behaviours. Erden (2007, p. 13) defines education as the process of creating a behavioural change in individuals through their own experiences.

Learning takes place as a result of individuals' interaction with their environment. Saban (2014, p. 172) defines learning as the change of knowledge, attitude and behaviour that occur in an individual as a result of his/her own life experiences. From the past to present, the term 'learning' has been a concept that many philosophers and scientists have attempted to explain. As a result of scientists evaluating this concept from different perspectives, there exist several learning approaches.

Many studies have revealed that the learner must be active in the learning process in order for the information to be coded in a meaningful way and to be used when it is required in the individual's life. Therefore, it is against the nature of learning for students to be completely passive in the learning process.

Effective learning can be achieved by having learners who construct knowledge by providing active participation throughout the learning process together with qualified learning environments. Today, there are many learning theories and approaches that are based on this approach and enable students to construct knowledge. With the development of technology and its use in education, in some contemporary learning models, even learning processes that are alternative to formal education in schools have been proposed in terms of temporal and spatial learning processes.

Today, as in many fields, technological progress has been made in the field of education, and educational processes have been enriched in terms of the materials used, with technological devices and both applications and software. Thanks to these materials, educational activities can be carried out in synchronous or asynchronous ways. When the relevant literature is reviewed, it can be seen that several learning models based on active use of educational technologies are suggested. Mobile learning, internet-based learning are distance learning are among these suggestions.

In order to enhance learning processes and increase efficiency in education, learning activities should be carried out efficiently and planned carefully. The limitations in learning environments can be minimised with the development of technology and educational technologies. At this point, mobile learning, where sustainable communication and interaction can be provided in a virtual environment, can be used.

Mobile learning is a contemporary learning model that eliminates time and space limitations (Ozer, 2017; Tanriverdi, 2011; Torun \& Dargut, 2015). It can be used to support traditional education or to deliver distance education. In this model, learning activities are carried out on smart mobile phones and tablet devices.

The term mobile learning emerged as a result of the emergence of portable technological devices and the use of these devices within the scope of distance education. From this point of view, mobile learning can be evaluated within the framework of distance education. According to several approaches, mobile learning (m-learning) is associated with e-learning and distance education.

The approach put forward by Gergiev (2004) cited in Tanriverdi (2011) shows the relationship between learning paradigms. This approach shows m-learning as a part of e-learning and e-learning as a part of distance education. At the same time, an m-learning activity is considered as an e-learning activity, and an e-learning activity is considered as a distance education activity. According to this approach, e-learning has emerged as a result of the development of computer and Internet technologies and the introduction of new methods for distance education. It was stated that distance education methods, such as television broadcasting, were used before e-learning methods emerged. 
However, m-learning has emerged as a part of the existing e-learning and distance education paradigms, thanks to the development of mobile technologies.

The emergence of new generation mobile devices, especially the adoption and use of Android and iOS-based smartphones and tablet computers, has led to the emergence and spread of m-learning. The fact that mobile vehicles are portable, enable social interaction and provide the opportunity to collect real-time data according to the location, time and environment creates several educational opportunities in terms of connecting with other mobile devices or networks, allowing individualisation (Klopfer, Squire, Holland \& Jenkins, 2002 cited in Bozkurt, 2015).

\subsection{Problem of the study}

The effectiveness and functionality of different models and techniques in education can only be demonstrated and proved through scientific studies. Therefore, it is important to examine and evaluate the studies carried out in a field. From this point of view, in this study, first, all mobile technology studies conducted in Turkey were thoroughly scanned. Then, the ones related to music education were selected and planned to be analysed and evaluated.

The problem of this study is to determine which studies involving mobile technologies have been carried out in the field of music education in Turkey and to analyse and evaluate these studies.

\subsection{Objective of the study}

The main objective of this research is to analyse the mobile technology studies carried out in the field of music education in Turkey. Within the scope of this general purpose, the answers to the following questions were sought in the study:

1. What is the imprint information of mobile technology studies carried out in the field of music education in Turkey?

2. How is the numerical distribution of mobile technology studies conducted in the field of music education in Turkey by years?

3. How is the numerical distribution of mobile technology studies conducted in the field of music education in Turkey according to subjects of the studies?

4. How is the numerical distribution of academic studies examining the functionality of mobile technologies in the field of music education in Turkey by the types of publication?

5. Which mobile technologies (mobile device or mobile application) have been used in the mobile technology-related studies in the field of music education in Turkey?

6. How is the distribution of mobile application used in mobile technology studies in the field of music education in Turkey according to the field they are related to?

With the thought of contributing to the literature, this study is thought to be significant in terms of revealing and examining the current situation regarding mobile technology studies carried out in the field of music education in Turkey.

This study is limited to the following:

- Studies carried out in the field of music education on mobile technologies in Turkey until October 2020;

- Studies on Google, Google Scholar, ULAKBIM, DergiPark, Marmara University and Higher Education Council (YOK) thesis centre databases'

- Studies on music that can be accessed by using the keywords 'mobile learning, m-learning, mobile learning, m-learning, information technologies, mobile technology, mobile application, mobile technology, technology'.

In this study, it is assumed that all the studies carried out in the field have been reached with the keywords used in the literature review. 


\section{Methodology}

In this section, the design of the research, databases used, data collection and data analysis methods are explained in detail.

In this study, the general survey model, which is one of the descriptive research methods, was used. The general survey model is the scanning made on the whole of the universe or on the sample to be taken from it in order to make a general judgement in a universe consisting of many elements (Karasar, 2004, p. 83). In this study, the literature review method, which is also one of the survey models, was used in order to evaluate the mobile technology studies conducted in the field of music education in Turkey. The obtained data were visualised using tables and the answers to the research questions were sought.

In the study, using the keywords 'mobile learning, m-learning, mobile learning, m-learning, information technologies, mobile vehicle, mobile application, mobile technology, technology' in the titles and content of the studies on mobile technologies in music education, the databases Google, Google Scholar, ULAKBIM, DergiPark, Marmara University and Higher Education Council (YOK) thesis centre were searched.

In the study, in which the principles of document analysis were adopted during the data collection process, articles, symposiums, congresses, book chapters and theses on mobile technologies in the field of music education in Turkey were examined.

The studies included in the scope of the research were evaluated in terms of the imprint information, the numerical distribution by years, the numerical distribution by subject, the numerical distribution of the studies examining the functionality of mobile technologies by the type of publication, the numerical distribution of the mobile technologies used according to the type of publication and the numerical distribution of the mobile application used according to the field to which they are related.

During the research process, 55 mobile technology studies conducted in the field of music education in Turkey were reached as a result of scanning the relevant databases. When the contents of the studies were examined, 20 studies were eliminated because they were considered irrelevant. Thus, a total of 35 studies, including 13 theses, 15 articles, 5 presentations and 2 book chapters, were included in the study. The studies examined within the scope of the study are limited to the studies that can be accessed from the relevant databases.

In this study, while analysing the data, the document analysis principles were adopted. The 35 studies included in the scope of the study were examined in detail, and the findings obtained for the sub-objectives of the study are presented in tables. Later, these findings are evaluated and a conclusion section is created about the studies included in the study. Some suggestions are made based on the results of the study.

\section{Findings}

In this section, the findings obtained for the sub-objectives of the research are presented in tables.

\subsection{Findings regarding the imprint information of the mobile technology studies conducted in the field of music education in Turkey}

Table 1. Identification/imprint information of studies on mobile technologies

\begin{tabular}{cccl}
\hline$\#$ & $\begin{array}{c}\text { Type of } \\
\text { publication }\end{array}$ & Author/year & Name of the publication \\
\hline 1 & PhD thesis & Aras (2020) & $\begin{array}{l}\text { A study on educational software development through } \\
\text { gamification method in instrument (Guitar) education }\end{array}$
\end{tabular}


Kuyumcu, K., Can, A. A. \& Can, U. K. (2021). Analysis of academic studies on mobile technologies in the field of music education in Turkey. New Trends and Issues Proceedings on Humanities and Social Sciences. 8(2), 37-48. Available from: www.prosoc.eu

$2 \quad$ Master thesis Cakan

Uzunkavak

$3 \quad$ PhD thesis

Tekeli (2019)

4

PhD thesis Kibici (2019)

Master thesis Satir (2019)

6

Master thesis Hardal (2018)

7

Master thesis Ilhan (2018)

8

Master thesis

Baloglu (2018)

9

Master thesis

Kocakaplan

(2018)

10

Master thesis

Kurun (2017)

11 Master thesis

Demirtas (2017)

Master thesis Andac (2016)

13 Master thesis

Ahmetzade

14 Article

15 Article

16

17

18

19

20

21

Article

22
Article
Aksoy and Nayir (2020)

Aras (2020)

Uygun (2020)

Ozcelik (2020)

Demirtas and Eroglu (2020)

Koksal (2019)

Gayretli (2019)

Kalkanoglu and Serin Ozparlak (2018)

Eroglu and Demirtas (2018)
Demirtas and
Assessment of the effectiveness of technology-supported teaching in individual voice education courses of fine arts high schools

A research on the usability of accessible and assistive music technologies (example of people with disability)

Development and evaluation of a software programme specifically designed for music courses within the framework of primary education curriculum

An analysis of the usability of music games designed for mobil devices in teaching of music lesson

The effect of music technology applications on success in musical hearing reading and writing teaching

Multi vocalisation analysis of the songs in secondary school music text books with digital software

The reflections of the transformations in digital technologies to production, consumption and sharing practices: assessment essay on social media and mobile music platforms

The music application usage cases of music teacher candidate on mobile devices

Investigations on the use of music teacher's candidates 'current music software for supporting school songs

Views of music teacher candidates regarding the use of digital audio workstation software as a tool for developing teaching material

The effect of technology usage on 4th and 5th grade primary school students attitudes towards music lessons Interactive educational software for basic knowledge of turkish music theory

Parent and expert opinions on the use of online and offline distance education tools in violin training with the Suzuki method An evaluation on students' opinion about mobile application titled 'Guitarist; developed through gamification method Investigation of videos providing instrument training in YouTube environment in terms of various variables

A study on developing attitude scale towards music software

Student opinions on the use of digital audio workstation software in material development

Recognition and use of music software of students of music education department

The use of smart phones in the professional sense of conservatory music department students

Analysis of Piano instruction software used in mobile devices

The use of digital audio workstation software as a tool for developing teaching material: a scale development study 


\begin{tabular}{|c|c|c|c|}
\hline 23 & Article & $\begin{array}{l}\text { Can and Aras } \\
(2017)\end{array}$ & $\begin{array}{l}\text { The evaluation of teacher's point of views about the practice of } \\
\text { information technologies in primary education music class }\end{array}$ \\
\hline 24 & Article & $\begin{array}{l}\text { Arici and Guner } \\
\text { (2017) }\end{array}$ & $\begin{array}{l}\text { A research on use of educational music applications at mobile } \\
\text { devices, by middle schools students }\end{array}$ \\
\hline 25 & Article & $\begin{array}{l}\text { Oztosun } \\
\text { Caydere (2016) }\end{array}$ & Relation of life-long learning and social media in music education \\
\hline & Article & $\begin{array}{l}\text { Onder and Yildiz } \\
\text { (2015) }\end{array}$ & The use of Tablet PC (iPad) in music applications \\
\hline 27 & Article & $\begin{array}{l}\text { Lehimler and } \\
\text { Sengul (2014) }\end{array}$ & $\begin{array}{l}\text { The analysis of contributions of music software on the Piano } \\
\text { education }\end{array}$ \\
\hline & Article & Ayhan (2012) & $\begin{array}{l}\text { The importance of usage the educational video in musical } \\
\text { instrument education in a world which has been surrounded by } \\
\text { social networks }\end{array}$ \\
\hline & $\begin{array}{l}\text { Congress } \\
\text { presentation }\end{array}$ & $\begin{array}{l}\text { Canyakan } \\
(2017)\end{array}$ & Technological trends in music education \\
\hline & $\begin{array}{l}\text { Symposium } \\
\text { presentation }\end{array}$ & $\begin{array}{l}\text { Ozturk and } \\
\text { Abdusselam } \\
\text { (2017) }\end{array}$ & $\begin{array}{l}\text { Brain-computer interface-aided investigation on the effect of } \\
\text { number of student to attention and meditation in vocal training }\end{array}$ \\
\hline 31 & $\begin{array}{l}\text { Symposium } \\
\text { presentation }\end{array}$ & $\begin{array}{l}\text { Kurun and } \\
\text { Ayhan (2017) }\end{array}$ & $\begin{array}{l}\text { Investigations on the use of music teacher's candidates 'current } \\
\text { music software for supporting school songs }\end{array}$ \\
\hline 32 & Presentation & $\begin{array}{l}\text { Parasiz and Aras } \\
\text { (2012) }\end{array}$ & $\begin{array}{l}\text { The place and importance of technology in music and music } \\
\text { education }\end{array}$ \\
\hline 33 & $\begin{array}{l}\text { Symposium } \\
\text { presentation }\end{array}$ & $\begin{array}{l}\text { Levendoglu } \\
\text { (2004) }\end{array}$ & Technology-supported contemporary music education \\
\hline 34 & Book chapter & $\begin{array}{l}\text { Lehimler and } \\
\text { Cinar (2019) }\end{array}$ & Use of Web 2.0 tools in professional music education \\
\hline & Book chapter & Demirtas (2019) & $\begin{array}{l}\text { Mobile application suggestion suitable for inverted classroom } \\
\text { model for individual instrument lesson }\end{array}$ \\
\hline
\end{tabular}

Table 1 demonstrates that all scientific publications on mobile technology in music education in Turkey were published between the years 2004 and 2020. Among these studies, there are a total of 35 academic studies, including 13 theses ( $3 \mathrm{PhD}, 10 \mathrm{MA}$ ), 15 articles, 5 presentations and 2 book chapters.

\subsection{Findings regarding the distribution of mobile technology studies conducted in the field of music in Turkey by years}

Table 2. Numerical distribution of scientific publications on mobile technologies by years

\begin{tabular}{lcccccccc}
\hline \multirow{2}{*}{$\begin{array}{l}\text { Type of the } \\
\text { publication }\end{array}$} & \multicolumn{2}{c}{$\mathbf{2 0 0 4 - 2 0 0 9}$} & \multicolumn{2}{c}{$\mathbf{2 0 1 0 - 2 0 1 5}$} & \multicolumn{2}{c}{$\mathbf{2 0 1 6 - 2 0 2 0}$} & \multicolumn{2}{c}{ Total } \\
\cline { 2 - 9 } & $\boldsymbol{f}$ & $\mathbf{\%}$ & $\boldsymbol{F}$ & $\mathbf{\%}$ & $\boldsymbol{F}$ & $\mathbf{\%}$ & $\boldsymbol{f}$ & \% \\
\hline Thesis & 0 & 0 & 1 & 2.86 & 12 & 34.29 & 13 & 37.14 \\
Article & 0 & 0 & 3 & 8.57 & 12 & 34.29 & 15 & 42.86 \\
Presentation & 1 & 2.86 & 1 & 2.86 & 3 & 8.57 & 5 & 14.29 \\
Book chapter & 0 & 0 & 0 & 0 & 2 & 5.71 & 2 & 5.71 \\
Total & 1 & 2.86 & 5 & 14.29 & 29 & 82.86 & $(f) 35$ & $(\%) 100$ \\
\hline
\end{tabular}


When Table 2 is examined, the frequency and percentage distribution of mobile technology-based scientific publications by years are as follows: 1 presentation (2.86\%) between 2004 and 2009; a total of 5 studies (14.29\%) between 2010 and 2015, including 1 thesis (2.86\%), 3 articles (8.57\%) and 1 presentation (2.86\%); and a total of 29 studies (82,86\%) between 2016 and 2020, including 12 theses (34.29\%), 12 articles (34.29\%), 3 presentations (8.57\%)) and 2 book chapters (5.71\%).

3.3. Findings regarding the sub-purpose of the subject distribution of the mobile technology studies conducted in the field of music education in Turkey

Table 3. Numerical distribution of scientific publications with mobile technology content by subject

\begin{tabular}{lcc}
\hline \multicolumn{1}{c}{ The subject of the studies } & $\boldsymbol{F}$ & $\%$ \\
\hline Analysis of the current situation & 14 & 40 \\
Examining the functionality & 11 & 31.46 \\
Examining perspectives & 8 & 22.86 \\
Scale development & 2 & 5.71 \\
Total & 35 & 100 \\
\hline
\end{tabular}

When Table 3 is examined, the frequency and percentage distribution of scientific studies on mobile technologies by subjects is as follows: $14(40 \%)$ studies are on the current situation analysis of mobile technologies, $11(31.43 \%)$ studies are on the functionality, $8(22.86 \%)$ studies are related to the perspectives and $2(22.86 \%)$ are the scale development.

\subsection{Findings regarding sub-purpose for the distribution of the studies on the functionality of mobile} technologies by the type of publication

Table 4. Distribution of academic studies by publication type

\begin{tabular}{lcc}
\hline Type of publication & $\boldsymbol{F}$ & $\%$ \\
\hline Thesis & 8 & 72.73 \\
Article & 2 & 18.18 \\
Presentation & 1 & 9.09 \\
Book chapter & 0 & 0 \\
Total & 11 & 100 \\
\hline
\end{tabular}

When Table 4 is examined, the numerical distribution of academic studies examining the functionality of mobile technologies according to the type of publication is 8 theses (72.73\%), 2 articles (18.18\%) and 1 presentation (9.09\%).

3.5. Findings regarding the sub-purpose of mobile technologies (mobile device or mobile application) used in mobile technology studies conducted in the field of music education in Turkey

Table 5. Numerical distribution of mobile technologies used in academic studies examining the functionality of mobile technologies by type of publication

\begin{tabular}{|c|c|c|c|}
\hline Type of publication & Thesis & Article & Presentation \\
\hline & $\begin{array}{l}\text { 1. A mobile app } \\
\text { called 'Gitarist' } \\
\text { 2. WhatsApp } \\
\text { 3. PowerPoint }\end{array}$ & $\begin{array}{l}\text { 1. Skype } \\
\text { 2. WhatsApp } \\
\text { 3. Sibelius }\end{array}$ & \\
\hline
\end{tabular}




\begin{tabular}{|c|c|c|c|}
\hline & 4. YouTube & & \\
\hline & 5. Powtoon & & \\
\hline \multirow[t]{13}{*}{ Mobile applications } & 6. Kahoot & & \\
\hline & 7. A learning & & \\
\hline & $\begin{array}{l}\text { software } \\
\text { developed for }\end{array}$ & & \\
\hline & the study & & \\
\hline & 8. Rhythm cat & & \\
\hline & 9. Garageband & & \\
\hline & 10. Perfect ear & & \\
\hline & 11. Finale & & \\
\hline & 12. Tonica Fugata & & \\
\hline & Overture & & \\
\hline & $\begin{array}{l}\text { 13. Music ace, } \\
\text { (cool edit), }\end{array}$ & & \\
\hline & $\begin{array}{l}\text { 14. Electronic } \\
\text { Instrument } \\
\text { (guitar) }\end{array}$ & & \\
\hline & $\begin{array}{l}\text { 15. A teaching } \\
\text { software } \\
\text { developed for } \\
\text { the study }\end{array}$ & & \\
\hline \multirow[t]{3}{*}{ Mobile devices } & 1. Smartphone & 1. Mobile phone & 1. NeuroSky \\
\hline & 2. Tablet & 2. Laptop & MindWave \\
\hline & 3. NoteWork & computer & mobile device \\
\hline
\end{tabular}

When Table 5 is examined, the distribution of mobile applications and devices used in academic studies examining the functionality of mobile technologies is as follows: there are 15 mobile applications and 3 mobile devices in thesis studies, 3 mobile applications and 2 mobile devices in article studies and only 1 mobile device in presentations.

\subsection{Findings regarding the sub-purpose for the distribution of mobile application used in the mobile technology studies according to the related fields}

Table 6. Distribution of mobile application used in academic studies according to the related fields

\begin{tabular}{|c|c|c|c|c|}
\hline \multicolumn{4}{|c|}{ Music applications } & \multirow[t]{2}{*}{ Other applications } \\
\hline $\begin{array}{l}\text { Educational } \\
\text { applications }\end{array}$ & $\begin{array}{l}\text { Virtual instrument } \\
\text { applications }\end{array}$ & $\begin{array}{l}\text { Notation } \\
\text { applications }\end{array}$ & $\begin{array}{l}\text { Voice recording } \\
\text { applications }\end{array}$ & \\
\hline $\begin{array}{l}\text { 1. A mobile app } \\
\text { called 'Gitarist' } \\
\text { 2. A software } \\
\text { developed for } \\
\text { the study } \\
\text { 3. A software } \\
\text { developed for } \\
\text { the study } \\
\text { 4. Perfect ear } \\
\text { 5. Rhythm cat }\end{array}$ & $\begin{array}{l}\text { 6. Electronic } \\
\text { Instrument } \\
\text { (Guitar) }\end{array}$ & $\begin{array}{l}\text { 7. Finale } \\
\text { 8. Tonica Fugata } \\
\text { Overture } \\
\text { 9. Sibelius }\end{array}$ & $\begin{array}{l}\text { 10. Music ace, } \\
\text { (cool edit), } \\
\text { 11. Garageband }\end{array}$ & $\begin{array}{l}\text { 12. WhatsApp } \\
\text { 13. PowerPoint } \\
\text { 14. YouTube } \\
\text { 15. Powtoon } \\
\text { 16. Kahoot } \\
\text { 17. Skype }\end{array}$ \\
\hline
\end{tabular}


Kuyumcu, K., Can, A. A. \& Can, U. K. (2021). Analysis of academic studies on mobile technologies in the field of music education in Turkey.

New Trends and Issues Proceedings on Humanities and Social Sciences. 8(2), 37-48. Available from: www.prosoc.eu

When Table 6 is examined, in the distribution of mobile applications used in academic studies, there are 6 application in non-music domains and 10 in music domains. It is seen that the most used application related to the field of music are educational applications (5), notation applications (3), sound recording applications (2) and virtual instrument applications (1).

\section{Results and suggestions}

\subsection{Results}

In this section, the results obtained from the findings regarding the sub-objectives of the research are presented. In addition, some suggestions were made based on these findings and results.

According to the data obtained from the findings of this current study, the imprint information of publications on mobile technologies is presented in Table 1. The data revealed that there were no scientific publications about mobile technologies in the music education literature before 2004; all studies were carried out between 2004 and 2020, which are 35 presentations in total including 13 thesis ( $3 \mathrm{PhD}, 10 \mathrm{MSc}$ ), 15 articles, 5 presentations and 2 book chapters.

Within the scope of the second sub-aim of the research, the studies carried out from 2004, when the first study on mobile technology was carried out, until 2020 were examined and these studies were grouped under three categories. Table 2 demonstrates all studies between the years 2004 and 2009, 2010 and 2015 and 2016 and 2020 with their frequency and percentage distributions according to the type of publication. In this study, it was also observed that the highest number of studies (29 studies, 82.86\%) was conducted between 2016 and 2020, and the least number of studies (1 study, 2.83\%) was carried out between 2004 and 2009. In line with these findings, it can be said that the number of academic studies on mobile technologies in music education has increased gradually in recent years. It has been observed that there has been a significant increase in the number of studies carried out especially after the year 2016. This situation can be associated with the development of technology and the interest in reflecting this development on education (Andac, 2016; Aras, 2020; Arici \& Guner, 2017; Can \& Aras, 2017; Kibici, 2019).

When the frequency and percentage distribution of mobile technology-based scientific studies, which is the third sub-purpose of the study, were analysed numerically, it was seen that mobile technology-based scientific publications were distributed under four topics, and these topics can be listed as current situation analysis, examination of its functionality, perspective analysis and scale development studies. In line with the findings obtained, it was observed that the studies with mobile technology increased the most in current situation analysis studies (14 studies, 40\%) in the first place and in the studies examining the functionality in the second place (11 studies, $31.43 \%$ ). The fact that researchers' tendencies are gaining weight in these aspects suggests that it is important to reveal the current state of mobile technologies and to test the functionality of these technologies, which can be a model for other studies. Based on the findings, it was seen that there were also studies in which the opinions of the target audience who would use mobile technologies were examined (8 studies, $22.86 \%$ ) and scale development for mobile technology use (2 studies, $5.71 \%$ ) was conducted.

Within the scope of the fourth sub-aim of the study, 11 academic studies examining the functionality of mobile technologies were examined, and the distribution of these studies by type of publication is presented in Table 3. In the data obtained, it was seen that the most studies were in the type of thesis (8 studies), two studies were articles and one study was a presentation. This situation suggests that it is necessary to investigate the functionality of mobile technologies in more in depth in terms of time, method and various variables, and that thesis studies may provide deeper opportunities and understanding in this regard.

The distribution of mobile application and devices used in academic studies examining the functionality of mobile technologies within the scope of the fifth sub-objective of the study is presented in Table 4 by the type of publication. In the data obtained, it was seen that mobile 
application was used mostly in studies conducted in thesis type (15), only three mobile applications were used in article studies, and no mobile application was used in one study in a presentation. This situation can be explained by the fact that studies examining the functionality of mobile technologies are conducted mores theses and theses offer the opportunity to make more in-depth research. It was also seen that the mobile devices used in thesis and article studies were smart mobile phones, laptops and tablets, and in one presentation study, the NeuroSky MindWave mobile device was used.

The distribution of mobile application used in academic studies examining the functionality of mobile technologies within the scope of the sixth and last sub-purpose of the study, according to the relevant area, is presented in Table 5 . In this analysis, it was seen that the most used mobile applications (10) in these studies were directly related to the music field, while the other (6) mobile applications used were non-music applications. Considering the sub-dimensions of the most used mobile application related to the music field, their distribution includes educational applications (5), notation applications (3), sound recording applications (2) and virtual instrument applications (1). In line with these findings, it is stated that mobile technologies are used in music education in limited numbers. Considering technological advances, it can be stated that this is not at the required or expected level.

\subsection{Suggestions}

- Even though it can be observed that there has been an increase in the number of mobile technology studies in recent years, increasing the number of these studies may contribute to the literature.

- Music education programmes where music education processes are carried out with modern learning models, such as mobile learning using mobile technologies, can be implemented.

- Educational technologies and mobile technologies can be used as supportive material for educational processes in music education.

- Considering the widespread use of smart phones and the high rate of access to these devices, using these devices in educational processes can offer various opportunities to increase the quality of education.

- In order for music educators, who are the leaders of music education, to use mobile technologies in their education processes, seminars can be organised to increase their knowledge and experience on this subject.

- Up-to-date information about mobile devices and mobile applications developed by various operating system companies can be included in the programmes of professional music education institutions.

- Mobile applications for all levels of music education can be developed within the scope of academic studies and various projects supported by institutions such as TUBITAK.

\section{References}

Ahmetzade, E. (2013). Turk muziginde temel nazari bilgiler konulu etkilesimli ogretim yazilimi (Unpublished master thesis). Gazi Universitesi Egitim Bilimleri Enstitusu, Ankara, Turkey.

Aksoy, Y. \& Nayir, A. E. (2020). Suzuki yontemi ile keman egitiminde cevrimici ve cevrimdisi uzaktan egitim araclarinin kullanimina iliskin aile ve uzman gorusleri. Akademik Sosyal Arastırmalar Dergisi, 104, 442-465.

Andac, Y. (2016). Muzik dersinde teknoloji kullanımının ilkogretim 4. ve 5. sinif ogrencilerinin muzik dersine karsi tutumlarina etkisi (Unpublished master thesis). Nigde Universitesi Egitim Bilimleri Enstitusu, Nigde, Turkey.

Aras, T. (2020a). Calgi (gitar) egitiminde oyunlastirma yontemine yonelik egitsel yazilim gelistirme calismasi (Unpublished doctoral dissertation). Marmara Universitesi Egitim Bilimleri Enstitusu, Istanbul, Turkey. 
Kuyumcu, K., Can, A. A. \& Can, U. K. (2021). Analysis of academic studies on mobile technologies in the field of music education in Turkey.

New Trends and Issues Proceedings on Humanities and Social Sciences. 8(2), 37-48. Available from: www.prosoc.eu

Aras, T. (2020b). Oyunlastirma yontemi dogrultusunda gelistirilen 'gitarist' adli mobil uygulamaya yonelik ogrenci goruslerinin degerlendirilmesi. GSED, 26, 366-373.

Arici, I. \& Guner, E. (2017). Ortaokul ogrencilerinin mobil cihazlardaki egitsel muzik uygulamalarını kullanimlarina yonelik bir arastIrma. Elementary Education Online, 16(4), 1897-1907.

Ayhan, A. (2012). Sosyal aglarin kusattigi bir dunyada calgi egitiminde egitsel video kullaniminin onemi. The Journal of Academic Social Science Studies, 5(8), 171-178.

Baloglu, U. (2018). Dijital teknolojilerdeki donusumlerin, muzik uretim, tuketim ve paylasim pratiklerine yansimalari: sosyal medya ve mobil muzik platformlari uzerinden bir degerlendirme denemesi (Unpublished master thesis). Yildiz Teknik Universitesi Sosyal Bilimler Enstitusu, Istanbul, Turkey.

Buyukozturk, S., Cakmak, E. K., Ozcan, E. A., Karadeniz, S. \& Demirel, F. (2009). Bilimsel Arastirma Yontemi (4th ed.). Ankara, Turkey: Pegem Akademi Yayinlari.

Can, A. A. \& Aras, T. (2017). Bilisim teknolojilerinin ilkogretim muzik dersinde kullaiımina yonelik ogretmen goruslerinin degerlendirilmesi. Ataturk Universitesi Guzel Sanatlar Enstitusu Dergisi, 39, 9-30.

Canyakan, S. (2017, September). Muzik egitiminde teknolojik yonelimler. Usak Universitesi 1. Uluslararasi Egitim Arastirmalari ve Ogretmen Egitimi Kongresi. Usak, Turkey.

Cakan Uzunkavak, M. (2020). Guzel sanatlar liseleri bireysel ses egitimi derslerinde teknoloji destekli ogretimin etkililiginin degerlendirilmesi (Unpublished master thesis). Bursa Uludag Universitesi Egitim Bilimleri Enstitusu, Bursa, Turkey.

Demirtas, E. (2017). Muzik ogretmeni adaylarının ogretim materyali gelistirme aracı olarak ses kayit ve duzenleme programlarının kullanilmasina yonelik gorusleri (Unpublished master thesis). Gazi Universitesi Egitim Bilimleri Enstitusu, Ankara, Turkey.

Demirtas, E. (2019). Bireysel calgi dersi icin ters yuz sinif modeline uygun mobil uygulama onerisi. In H. Yucel \& S. Turkel Oter (Ed.), Muzik kulturune dair cesitli gorusler III (pp. 47-73). Konya, Turkey: Egitim Yayinevi.

Demirtas, E. \& Ozcelik, S. (2020). Muzik yazilimlarina yonelik tutum olcegi gelistirme calismai. Studies Education, 15(3), 1715-1727.

Erden, M. (2007). Egitim Bilimine Giris (6th ed.). Ankara, Turkey: Arkadas Yayinlari.

Eroglu, T. \& Demirtas, E. (2018). Ses kayit ve duzenleme programlarinin ogretim materyali gelistirme araci olarak kullanilmasi: Bir olcek gelistirme calisması. Ataturk Universitesi Guzel Sanatlar Enstitusu Dergisi, 41, 48-59.

Gayretli, S. (2019). Konservatuvar muzik bolumu ogrencilerinin mesleki acidan akilli telefon kullanımlari uzerine bir inceleme. Kafkas Universitesi e-Kafkas Egitim Arastirmalari Dergisi, 6(1), 11.

Hardal, B. (2018). Muziksel isitme okuma yazma dersi ogretiminde muzik teknolojileri uygulamalarının basarıya etkisi (Unpublished master thesis). Ondokuz Mayis Universitesi Egitim Bilimleri Enstitusu, Samsun, Turkey.

Ilhan, S. Y. (2018). Ortaokul muzik ders kitaplarında yer alan sarkilarin dijital muzik yazilimlari ile cokseslendirme analizi (Unpublished master thesis). Inonu Universitesi Egitim Bilimleri Enstitusu, Malatya, Turkey.

Kalkanoglu, B. \& Serin Ozparlak, C. (2018). Piyano egitimi acisindan mobil cihazlarda kullanilan yazilımların incelenmesi. Akademik Sosyal Araştırmalar Dergisi, 69, 354-363.

Karasar, N. (2004). Bilimsel Arastırma Yontemi (23rd ed.). Ankara, Turkey: Nobel Akademik Yayincilik Egitim Danismanlik Tic. Ltd. Sti.

Kibici, V. B. (2019). Ilkokul mufredatına uygun muzik dersi egitim yazilim programinin gelistirilmesi ve uygulanmasının degerlendirilmesi (Unpublished doctoral dissertation). Necmettin Erbakan Universitesi Egitim Bilimleri Enstitusu, Konya, Turkey.

Kocakaplan, Y. (2018). Muzik ogretmeni adaylarının mobil cihazlardaki muzik uygulamalarını kullanım durumlari (Unpublished master thesis). Gazi Universitesi Egitim Bilimleri Enstitusu, Ankara, Turkey.

Koksal, S. (2019). Muzik egitimi anabilim dalı ogrencilerinin muzik yazılımlarini tanima ve kullanma durumlari. Sanat ve Insan Dergisi, 3(1), 1309-7156.

Kurun, A. R. (2017). Muzik ogretmeni adaylarının guncel muzik yazilımlarini okul sarkilarına destek amacli kullanmalarına yonelik goruslerinin incelenmesi (Unpublished master thesis). Inonu Universitesi Egitim Bilimleri Enstitusu, Malatya, Turkey. 
Kuyumcu, K., Can, A. A. \& Can, U. K. (2021). Analysis of academic studies on mobile technologies in the field of music education in Turkey.

New Trends and Issues Proceedings on Humanities and Social Sciences. 8(2), 37-48. Available from: www.prosoc.eu

Kurun, A. R. \& Ayhan, A. (2017, October). Muzik ogretmeni adaylarinın guncel muzik yazilımlarini okul sarkilarina destek amacli kullanmalarinin incelenmesi. Kahramanmaras Sutcu Imam Universitesi 3. Uluslar arasi Sosyal Bilimler Sempozyumu Bildirisi. Kahramanmaras, Turkey.

Lehimler, E. \& Sengul, C. (2014). Muzik yazilimlarinin piyano egitimine katkilarinin incelenmesi. Ataturk Universitesi Sosyal Bilimler Enstitusu Dergisi, 18(2), 229-246.

Lehimler, E. \& Cinar, U. (2019). Mesleki muzik egitiminde web 2.0 araclarinin kullanimi. In H. Arapgirlioglu \& S. Akka (Eds.). Guzel Sanatlar Alanında Yeni Ufuklar (pp. 47-73). Ankara, Turkey: Gece Kitapligi.

Levendoglu, N. O. (2004, April). Teknoloji destekli cagdas muzik egitimi. 1924-2004 Musiki Muallim Mektebinden Gunumuze Muzik Ogretmeni Yetistirme Sempozyumu Bildirisi. Isparta, Turkey.

Oran, M. K. \& Karadeniz, S. (2007 January-February). Internet tabanli uzaktan egitimde mobil ogrenmenin rolu. Dumlupınar Universitesi IX. Akademik Bilisim Konferansi Bildirileri. Kutahya, Turkey.

Onder, O. \& Yildiz, G. (2015). Muzik uygulamalarında tablet bilgisayar (ipad) kullanımi. Suleyman Demirel Universitesi Guzel Sanatlar Fakultesi Hakemli Dergisi, 15, 1308-2698.

Ozer, O. (2017). Mobil destekli ogrenme cevresinin yabanci dil ogrencilerinin akademik basarılarına, mobil ogrenme araclarinı kabul duzeylerine ve bilissel yuke etkisi (Unpublished doctoral dissertation). Universitesi Egitim Bilimleri Enstitusu, Istanbul, Turkey.

Oztosun Caydere, O. (2016). Muzik egitiminde hayat boyu ogrenme ve sosyal medya iliskisi International Journal of Human Sciences, 13(1), 745-753.

Ozturk, S. \& Abdusselam, M. S. (2017, October 28). Ses egitimi derslerinde kisi sayisinin dikkat ve rahatlik-sakinlik durumuna etkisinin beyin-bilgisayar arayuzu destekli incelenmesi. Sivas Cumhuriyet Universitesi Uluslararasi Egitim Teknolojileri Sempozyumu, Sivas, Turkey.

Parasiz, G. \& Aras, T. (2012), Teknolojinin muzik ve muzik egitimi alanindaki yeri ve onemi Ataturk Universitesi Sosyal Bilimler Enstitusu Dergisi, 18(2), 29-246.

Saban, A. (2014). Ogrenme Ogretme Sureci (7th ed.). Ankara, Turkey: Nobel Akademi Yayincilik.

Satir, U. K. (2019). Mobil cihazlar icin tasarlanmis muzik oyunlarının muzik dersi ogretiminde kullanılabilirliginin incelenmesi (Unpublished master thesis). Ataturk Universitesi Egitim Bilimleri Enstitusu, Erzurum, Turkey.

Seylan, F. (2018) Mobil Ogrenmenin Akademik Basariya Etkisi Uzerine Yapilan Deneysel Calismaların Karsilastirillmasi (Unpublished master thesis). Yuzuncu Yil Universitesi Egitim Bilimleri Enstitusu, Van, Turkey.

Tanriverdi, M. (2011). E-ogrenmeye destek amaçlı mobil ogrenme uygulamasi gelistirme ve etkilerinin incelenmesi (Unpublished master thesis). Gazi Universitesi Bilisim Enstitusu, Ankara, Turkey.

Tekeli, B. (2019). Erisilebilir ve yardıma muzik teknolojilerinin kullanılabilirligine iliskin bir arastirma (engelli bireyler ornegi). Ankara, Turkey: Gazi Universitesi Egitim Bilimleri Enstitusu.

Torun, F. \& Dargut, T. (2015). Mobil ogrenme ortamlarinda ters yuz sinif modelinin gerceklestirilebilirligi uzerine bir oneri. Adnan Menderes Universitesi Egitim Fakultesi Egitim Bilimleri Dergisi, 6(2), 20-29.

Ucan, A. (1997). Muzik Egitimi: Temel Kavramlar, Ilkeler, Yaklasimlar (2nd ed.). Ankara: Muzik Ansiklopedisi Yayinlari.

Uygun, G. (2020). Muzik egitimi anabilim dalı ogrencilerinin muzik yazilimlarini tanima ve kullanma durumlari. Balkan Muzik ve Sanat Dergisi, 2(2), 13-26.

Yildirim, A. \& Simsek, H. (2013). Sosyal Bilimlerde Nitel Arastırma Yontemleri (9th ed.). Ankara, Turkey: Seckin Yayincilik.

Yildiz Avci, Z. (2018). Mobil ogrenme arastirmalari ve uygulamalarına iliskin bir meta analiz calismasi (Unpublished master thesis). Firat Universitesi Egitim Bilimleri Enstitusu, Elazig, Turkey. 